vided by a suspended illuminated ceiling. The wood block floor is of Rhodesian teak.

The library at present has a stock of 30,000 volumes, two-thirds of which are pariodicals. The present intake of periodicals is some 700 titles. For the first time the stock is arranged systematically, the whole library having been re-catalogued cver the past seven years according to Bliss's classification. Modifications to this scheme have been kept to a minimum, but some sections have been roarranged-notably by the use of Bentham and Hooker's numbering in systematic botany, so that the arrangement of the books matches that of the herbarium.

A few of the most interesting volumes were on view at the opening coremony and with them samples of the largo collection of photographs and valuable diarios recently bequeathed to the Gardon by the late Dr. J. F. Rock, whose plant collections from China are worldfamous.

A 22 -ft. strip all along the north sido of the first floor is cut off from the herbarium to form the photographer's studio and darkroom, workrooms for the two mycologists and the cytologist on the staff, a general laboratory and a culture room. There is an independent air extraction system for this part of the building. The laboratory has working space for 5-6 technical staff and is equipped for all normal routines in mycology, cytology or plant anatomy.

The unity of the herbarium itself, which is split betwoen two floors, is preserved by a small central well; above this there is a raised glass-brick section of roofing with underslung artificial lighting in false beams.

The herbarium is planned for maximum flexibility, with central storage of specimens and peripheral working space. Along the full length of the south side of each floor there is a free consultation bench which is not encroached on for permanent working places for staff; these are distributed around the other three sides of the top floor, and at the two ends of the lower floor.

The herbarium specimens are housed in specially designed steel cabinets: each contains two ranks of six pigeon-holes and they are stacked three high. In order to permit a simple magnetic closure each cupboard has a singl: door the inner flange of which is fitted with rubber containing a magnetized strip. This system gives effective dust-proofing and most acceptable silence of operation. The absence of catches or locks with moving parts will remove a constant demand for repair work. The single door demands very little more access space than the usual two half-doors, as this is largely governed not by the swing of the doors but by the depth needed to take out specimens. These cabinets are finishod in grey stove. enamel and were made and installed by Roneo, Ltd. Roughly one-third of the space is at present free for future accessions.

The herbarium now contains some two million specimens. Among the most interesting of the old collections is that of Paul Dietrich Giseke (1745-96), a pupil of Linnæus; his specimens include several from the garden at Uppsala and one that evidently came from Linnæus's own herbarium and bears his handwriting. Another very valuable herbarium is that of the great Edinburgh botanist Robert Kaye Greville (1794-1866); it contains specimens roceived from many of his famous botanical contem. poraries and is especially rich in cryptogams. It was, however, the collections made in south-west China by George Forrest that gave a new impetus to active taxonomy at Edinburgh, and from these collections there stemmed the work on Rhododendron, Primula and other Sino-Himalayan genera which brought the Royal Botanic Garden international fame.

Since the Second World War, China has been virtually closed to Western botanists and Edinburgh activity has tended on the one hand towards work on the flora of western Asia (stimulated by P. H. Davis's large Turkish colloctions), on the other towards the study of special groups.

On the day of the opening ceremony a fow small exhibits were put up; one showed the work of G. Forrest, already mentioned; others indicated the travel made by members of the staff in furtherance of present investigations. During the past seven years these have included collecting trips in Turkey, Afghanistan, Pakistan, Burma, Malaya, Sarawak and New Guinea. These were all illustrated by interesting specimens, photographs and living plantsfor the introduction of new materials to cultivation in the Garden has been an important aim of these expeditions.

On view in the library were preliminary modols and plans of the new greenhouses shortly to replace the existing front range, part of which has already had to be closed to the public for reasons of safety. This is the next phase of modernization at the Garden and will provide better facilities for research collections and even greater incentive to the search for new introductions and for advances in methods of presenting the plant world to students and to the general public.

\title{
OBITUARY
}

\section{Dr. W. O. Howarth}

OLDER members of the University of Manchester and friends throughout Britain will have read with regret of the doath at his home in Southport, on June 27, of Dr. W. O. Howarth, formerly senior lecturer in botany in the University of Manchester. He was in his seventyfourth yoar and is survived by his wife and son.

Dr. Howarth was at one time a student of the University of Manchester, graduating in 1913. Thereafter he was succossivoly assistant lecturor in botany at University College, Cardiff, and the University of Reading, with a break between during the First World War. He joined tho staff of the Botany Dopartment, Manchester, in 1919, and served successively under Profs. Woiss, Drummond, Ashby and Harland, until his retirement in 1956, in all completing upwards of forty years of academic teaching and research. During this period he contributed to the genoral courses, in particular to plant anatomy and ecology but, especially in his later years, he was responsible for all course work in botany and pharmacognosy for pharmacists. This he did with wide knowledgeability and devotion. In 1925 he was appointed an examiner for the Pharmaceutical Society of Great Britain, and continued in this capacity until aftor his retirement.

Dr. Howarth, who belonged to a generation of enthusias. tic field botanists, was one of the best, his knowledge of the Lancastrian flora, especially of the interosting coastal and adjacent regions around Southport, being unrivalled. In his research he was a recognized authority on some of the genera of grasses. His name is familiar to a very wide circle of botanists through the successful re-issue of Lowson's Textbook of Botany (written jointly with the late Dr. L. G. G. Warne). This volume, which has gone through several editions in Britain, was successfully adapted, by the judicious introduction of local examples, for use in India, Pakistan and Coylon. Howarth also collaborated in the production of a Practical Botany for home use and one for use in tropical countries.

To those who knew him well in his daily life, he was greatly liked for his unassuming modesty, an over-willing helpfulness and quiet, warm friendliness, and for a deep sincerity of purpose in his work. $\quad$ C. W. WARDLAW 